Original Article

\title{
In vitro antibacterial activities of silver nanoparticles synthesised using the seed extracts of three varieties of Phoenix dactylifera
}

\author{
Atividades antibacterianas in vitro de nanopartículas de prata sintetizadas usando \\ extratos de sementes de três variedades de Phoenix dactylifera
}

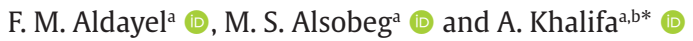 \\ ${ }^{a}$ King Faisal University, College of Science, Biological Sciences Department, Al Ahsa, Saudi Arabia \\ ${ }^{\mathrm{b} B e n i-S u e f}$ University, Faculty of Science, Botany and Microbiology Department, Beni-Suef, Egypt
}

\begin{abstract}
Green synthesis of silver nanoparticles (AgNPs) is an ecofriendly, cost-effective and promising approach for discovery of novel therapeutics. The aim of the current work was to biogenic synthesize, characterize AgNPs using seed extracts of three economically important varieties of date palm (Iklas, Irziz and Shishi), and assess their anti-pathogenic bacterial activities. AgNPs were synthesised then characterised using electron microscopy and Fourier transform infrared analyses. The bactericidal activities of AgNPs against five different bacterial pathogens, Bacillus subtilis, Escherichia coli, Staphylococcus aureus, methicillin-resistant Staphylococcus aureus and Streptococcus pneumoniae, were determined in vitro. In particular, changes in membrane integrity of virulent bacterial strains in response to AgNPs were investigated. Results of lactate dehydrogenase, alkaline phosphatase activity assays, and measurement of membrane potential revealed that the cytotoxic effects of the AgNPs were mainly centred on the plasma membrane of bacterial cells, leading to loss of its integrity and eventually cell death. In conclusion, green synthesis of AgNPs is an efficient, cost-effective and promising strategy to combat virulent antibiotic-resistant strains.
\end{abstract}

Keywords: Iklas, Irziz and Shishi, AgNPs, FTIR, antimicrobial activity,

\begin{abstract}
Resumo
A síntese verde de nanopartículas de prata (AgNPs) é uma abordagem ecologicamente correta, econômica e promissora para a descoberta de novas terapêuticas. O objetivo do presente trabalho foi sintetizar biogênica, caracterizar AgNPs usando extratos de sementes de três variedades economicamente importantes de tamareira (Iklas, Irziz e Shishi) e avaliar suas atividades bacterianas antipatogênicas. AgNPs foram sintetizados e caracterizados usando microscopia eletrônica e análise de infravermelho por transformada de Fourier. As atividades bactericidas de AgNPs contra cinco diferentes patógenos bacterianos, Bacillus subtilis, Escherichia coli, Staphylococcus aureus, Staphylococcus aureus resistente à meticilina e Streptococcus pneumoniae, foram determinadas in vitro. Em particular, foram investigadas alterações na integridade da membrana de cepas bacterianas virulentas em resposta a AgNPs. Os resultados da lactato desidrogenase, dos ensaios da atividade da fosfatase alcalina e da medição do potencial de membrana revelaram que os efeitos citotóxicos dos AgNPs estavam principalmente centrados na membrana plasmática das células bacterianas, levando à perda de sua integridade e, eventualmente, à morte celular. A síntese verde de AgNPs é uma estratégia eficiente, econômica e promissora para combater cepas virulentas resistentes a antibióticos.
\end{abstract}

Palavras-chave: Iklas, Irziz e Shishi, AgNPs, FTIR, atividade antimicrobiana.

\section{Introduction}

Green synthesis of silver nanoparticles (AgNPs) is an ecofriendly, cost-effective and promising approach for the discovery of novel therapeutics. Biologically synthesised AgNPs have been derived from various plants and microorganisms (Anandaradje et al., 2020; Balu et al., 2020). AgNPs have been synthesised from extracts from the leaves of plants such as Mimosa albida (Pilaquinga et al.,

2020), the bark of Picea abies (Tanase et al., 2020), and the leaf of Pistacia atlantica (Hamelian et al., 2020). AgNPs have previously been synthesised from extracts of different parts of the date palm: date palm pollen (Banu et al., 2018), leaf (Aitenneite et al., 2016), wood (Charti et al., 2017), fruit (Zafar and Zafar, 2019), and seeds (Mohammadi et al., 2020).

*e-mail: ashraf_zaky2002@yahoo.com; akhalifa@kfu.edu.sa

Received: August 15, 2020 - Accepted: December 15, 2020 
AgNPs have been documented as potent antimicrobial agents against many pathogenic agents including those with multidrug resistance strains ampicillin-resistant Escherichia coli, erythromycin-resistant Streptococcus pyogenes, methicillin-resistant Staphylococcus aureus (MRSA), Pseudomonas aeruginosa and vancomycin-resistant Staphylococcus aureus (Mohammed et al., 2018; Al-Brahim and Mohammed, 2020). The resistance of microbial pathogens to antibiotics is a pressing problem worldwide. Biologically synthesised nanoscale metal particles have been recently viewed as a promising innovative strategy to overcome this problem (Mohammadi et al., 2020). AgNPs are cost-effective, eco-friendly and easy to synthesise. The mechanism by which AgNPs exert their antimicrobial effects is likely to be disruption of cell membrane integrity and permeability, and generation of highly reactive oxygen species that can attack vital molecules inside the cells (Al-Brahim and Mohammed, 2020).

Phoenix dactylifera (date palm) is a member of the family Arecaceae (formerly known as palmae). P. dactylifera is the main crop in arid and semiarid regions of the world and plays pivotal social and economic roles of Gulf countries, particularly Saudi Arabia. The Kingdom of Saudi Arabia is considered one of the top countries in terms of the total number of palm trees (exceeds 28 million palms), and date production (FAO. 2011). Al-Ahsa is located in the Eastern Province of Saudi Arabia and is the largest date-palm oasis in the world. It has about three million trees, which are cultivated over 30,000 acres. It is particularly famous for the Iklas date.

Over the past two decades, date palm cultivation has been doubled and consequently the numbers of productive date palm trees have increased. There are more than 400 distinctive varieties of the date palms that are distributed across Saudi Arabia. Among the economically important varieties are Iklas, Irziz and Shishi. Little is known about the possibility of synthesising AgNPs from extracts of the well-known date varieties in Al Ahsa. Therefore, the aim of the current work was to synthesise and characterise AgNPs using three important date palm varieties - Iklas, Irziz and Shishi - to assess their anti-microbial potential.

\section{Materials and Methods}

\subsection{Synthesis of silver nanoparticles from extracts from three varieties of Phoenix dactylifera Seeds}

P. dactylifera seeds of three economically important varieties of date palm (Iklas, Irziz and Shishi), were collected from Al-Ahsa Farm, Saudi Arabia. The seeds were surface-sterilized using a $5 \% \mathrm{H}_{2} \mathrm{O}_{2}$ wash for $5 \mathrm{~min}$, followed by multiple rinses with sterile distilled water. Then, the seeds were soaked in distilled water for $1 \mathrm{~h}$, to remove the remaining date fruit on the periphery of the seed. The seeds were milled in $10 \mathrm{~mL}$ of sterile distilled water, using a grinder for $10 \mathrm{~min}$. The ground mixture was centrifuged at 10,000 rpm for $15 \mathrm{~min}$, and the supernatant was transferred into a brown bottle and kept in the dark for $24 \mathrm{~h}$. After incubation, the supernatant was mixed with an equal proportion of freshly prepared silver nitrate ( $1 \mathrm{mM} \mathrm{AgNO}_{3}$ ) and incubated for $3 \mathrm{~h}$ with shaking. A transformation of the colour of the solution from a semi-transparent pale yellow to brown was observed after 10-15 min of incubation and indicated the formation of AgNPs from the P. dactylifera seed extract. The Ag particle solution was dried and centrifuged using methanol at $10,000 \mathrm{rpm}$ for $10 \mathrm{~min}$ to remove the debris.

\subsection{Characterisation of the silver nanoparticles}

\subsubsection{Scanning electron microscopy}

To study the morphological characteristics of synthesised AgNPs, scanning electron microscopy (SEM) was carried out in various magnification ranges. The shape and size of the AgNPs were determined as previously described (Nagajyothi et al., 2012). SEM analysis by, the strains cultured on cover slips and the cover slips were fixed in $2.5 \%$ glutaraldehyde in $0.2 \mathrm{M}$ sodium cacodylate buffer with $\mathrm{pH} 7.2$, post fixed in $1 \%$ osmium tetroxide in $0.2 \mathrm{M}$ sodium cacodylate buffer with $\mathrm{pH} 7.2$, and serially dehydrated in ethyl alcohol. Afterward critical point drying, they were covered with gold using a sputter-coating system and examined with a scanning electron microscope.

\subsubsection{Fourier Transform Infrared Analysis}

The synthesised AgNPs were characterized by Fourier transform infrared (FTIR) analysis by following the standard method described previously (Nagajyothi et al., 2012; Nethradevi et al., 2012). Briefly, a pinch of the AgNPs was dissolved in $3 \mathrm{~mL}$ of the methanol and measured at the maximum wavelength by using FTIR spectroscopic analysis (FTIR-8400, Shimadzu, Japan) by the potassium bromide pellet (FTIR grade) method at a 1:100 ratio. The spectrum was determined with an FTIR Nicolet impact 400 Spectrophotometer (Bruker Optics GmbH, Ettlingen, Germany) using diffuse reflectance mode. FTIR measured from 500 to $1 \mathrm{~cm}$ to determine the functional group of the AgNPs.

\subsection{Determination of the Minimum Inhibitory Concentration}

The minimum inhibitory concentration (MIC) of the synthesised AgNPs against five different bacterial pathogens - B. subtilis, E. coli, S. aureus, MRSA and Strept. pneumonia - was determined using a standard protocol (Arasu et al., 2013). Briefly, the compounds were dissolved in dimethyl sulfoxide (5\% DMSO) and sterilized using a $0.2 \mu \mathrm{m}$ Millipore membrane filter. The solution was then serially diluted (two-fold in a 96-well microtiter plate) in the Mueller Hinton broth (MHB). An aliquot $(5 \mu \mathrm{L})$ of the freshly prepared bacterial suspensions of the test organism (at $1.5 \times 10^{6} \mathrm{CFU} \mathrm{mL}^{-1}$ ) was transferred into $200 \mathrm{~mL}$ of sterilized MHB. After mixing, the 96 -well microtiter plates were covered with a sterile plate sealer and incubated at $37{ }^{\circ} \mathrm{C}$ for $18 \mathrm{~h}$ under shaking. After incubation, $5 \mathrm{~mL}$ of the microbial cells in each well were spotted on Mueller Hinton agar plates and incubated at $37{ }^{\circ} \mathrm{C}$ for $18 \mathrm{~h}$. The visible growth was monitored to determine the MIC of the particles. The experiment was repeated three times to confirm the antibacterial activity of the AgNPs. 


\subsection{Mechanism of the antimicrobial activity of the silver nanoparticles}

\subsubsection{Alkaline phosphatase activity assay}

\subsubsection{Screening of alkaline phosphatase-producing bacteria}

The isolates of $S$. aureus and B. cereus were screened for alkaline phosphatase (ALP) activity by cultivating on Heart Infusion agar (Difco) containing $0.01 \%$ phenolphthalein bisphosphate tetrasodium salt (Sigma) and $10 \% \mathrm{NaCl}(\mathrm{w} / \mathrm{v}$ ) as per the method described by Helianti et al. (2007). After incubation at $37{ }^{\circ} \mathrm{C}$ for $1-2$ days, all pink colonies were selected as potential ALP-producing strains. All selected isolates were separately confirmed for their abilities to produce ALP: A loopful of the selected ALP-producing strain was inoculated into $5 \mathrm{~mL}$ of JCM no.377 broth and incubated on a rotary shaker at $37^{\circ} \mathrm{C}(150 \mathrm{rpm})$ for $24 \mathrm{~h}$ for the seed culture. The seed culture broth $(0.5 \mathrm{~mL})$ was transferred into $50 \mathrm{~mL}$ of modified JCM No. 377 broth in a $250 \mathrm{~mL}$ Erlenmeyer flask (in duplicate) and incubated as for the seed culture. The supernatant obtained after centrifugation of the cultures at $13,300 \mathrm{rcf}, 4^{\circ} \mathrm{C}$ for $10 \mathrm{~min}$ was used as crude enzyme for ALP activity detection.

\subsubsection{Alkaline phosphatase activity assay}

The ALP activity assay was done by the method described by Helianti et al. (2007). The reaction mixture composed of $1.0 \mathrm{~mL}$ of $10 \mathrm{mM}$ p-nitrophenylphosphate (pNPP) (Sigma) in $0.2 \mathrm{M}$ Tris- $\mathrm{HCl}$ buffer $\mathrm{pH} 10.0$ with $5 \mathrm{mM} \mathrm{MgCl}_{2}$, and $0.1 \mathrm{~mL}$ of the crude enzyme was incubated at $37^{\circ} \mathrm{C}$ for 15 min. The reaction was stopped with $1 \mathrm{~mL}$ of $1 \mathrm{M} \mathrm{NaOH}$ and its absorbance was measured at $405 \mathrm{~nm}$. One unit of ALP was defined as the amount of the enzyme yielding 1 $\mu \mathrm{M}$ of $\mathrm{p}$-nitrophenol in $1 \mathrm{~min}$ per mg protein under the assay conditions. The protein concentration was estimated by the Lowry method (Lowry et al., 1951) using bovine serum albumin as the standard.

\subsubsection{Measurement of membrane potential}

The experiment was carried out according to the method of Sánchez et al. (2010) with some modifications. In brief, an overnight culture of S. aureus and B. cereus was diluted with fresh nutrient broth to obtain a cell density of $1 \times 10^{7} \mathrm{CFU} \mathrm{mL} \mathrm{m}^{-1}$. The bacterial suspensions were subjected to treatment with extracts from three types of $P$. dactylifera (Iklas, Irziz and Shishi) as NPs and aqueous solutions at $25^{\circ} \mathrm{C}$ for $10 \mathrm{~min}$. Then, the treated bacterial suspensions were further incubated with $0.5 \mu \mathrm{g} \mathrm{mL}^{-1}$ of the membrane potential-sensitive fluorescent probe bis-(1,3-dibutyl barbituric acid) trimethine oxonol (DiBAC4(3); Life Technologies, Eugene, OR, USA) in the dark for 5 min. After incubation, the fluorescence intensity of DiBAC4(3) was measured using a fluorescence spectrophotometer (Cary Eclipse G9800A, Agilent technologies trading Co., Ltd., Shanghai, China) at excitation and emission wavelengths of $492 \mathrm{~nm}$ and $515 \mathrm{~nm}$, respectively. Background fluorescence resulting from 3-p-trans-coumaroyl-2-hydroxyquinic acid (CHQA) added to the medium was determined and corrected.

\subsubsection{Determining lactate dehydrogenase activity}

\subsubsection{Growth and harvesting of organisms}

Bacterial cultures of $S$. aureus and B. cereus were grown aerobically in 2.5 L flasks, containing $0.5-1.0 \mathrm{~L}$ of medium, on a reciprocal shaker at 80 cycles per min. All cultures were incubated at $37^{\circ} \mathrm{C}$. Cultures were harvested in the late exponential phase of growth by centrifugation at 2,500 rcf for $10 \mathrm{~min}$ at $4{ }^{\circ} \mathrm{C}$. Cells were washed once with $0.05 \mathrm{M}$ potassium phosphate buffer $(\mathrm{pH} 6.5)$ and stored at $-20^{\circ} \mathrm{C}$.

\subsubsection{Preparation of cell-free extracts}

Cells were suspended in approximately 20 volumes of $0.05 \mathrm{M}$ potassium phosphate buffer ( $\mathrm{pH}$ 6.5) and disrupted by three passages through a precooled French pressure cell. Cell debris was removed by centrifugation at 27,000 rcf for $15 \mathrm{~min}$ at $4^{\circ} \mathrm{C}$. Extracts prepared in this manner generally contained approximately $0.3 \mathrm{mg}$ of protein per $\mathrm{mL}$.

\subsubsection{Lactate dehydrogenase assay}

Prepared extracts were assayed immediately for lactate dehydrogenase (LDH) activity. The complete assay mixture contained the following components in a final volume of $1 \mathrm{~mL}: 50 \mu$ moles potassium phosphate buffer ( $\mathrm{pH} 6.5$ ), $2.5 \mu$ moles sodium pyruvate, $0.136 \mu$ moles reduced nicotinamide adenine dinucleotide (NADH2) and 1-10 $\mu \mathrm{g}$ of protein, depending on the activity of the extract. After measurement of the endogenous NADH2 oxidase activity, reactions were initiated by addition of pyruvate. The decrease in optical density at $340 \mathrm{~mA}$, resulting from the oxidation of NADH2, was followed with a Zeiss M4 QIII spectrophotometer (Carl Zeiss, Inc., New York, N.Y.) equipped with a Varicord model 43 recorder. Assays were conducted at $24{ }^{\circ} \mathrm{C}$. Specific activity was expressed as micromoles of NADH2 oxidized per minute per milligram of protein. The amount of ALP was measured by slightly modifying methods specified in (Arokiyaraj et al., 2014).

\subsection{Statistical analyses}

The experiment is designed as a complete randomized design. The data from all measurements are analyzed with ANNOVA/MANOVA of Statistica 6 software. The significance of differences among means was performed using Duncan's multiple range test at probability level of $\mathrm{p}=0.05$.

\section{Results and Discussion}

In the current study, AgNPs were synthesised using the seed extracts of three economically important varieties (Iklas, Irziz and Shishi) of P. dactylifera. The resulting green synthesised AgNPs were characterized using SEM (Figure 1) and FTIR analysis (Figure 2). The antibacterial activities of AgNPs against five different pathogenic bacterial strains were tested. The bactericidal effects of the AgNPs against the drug-resistant strains were assessed by determining the MIC, measurement of membrane potential, LDH, ALP activity and intracellular protein leakage.

In this study, the expected change in colour of the silver nitrate solution upon addition of the water extract 

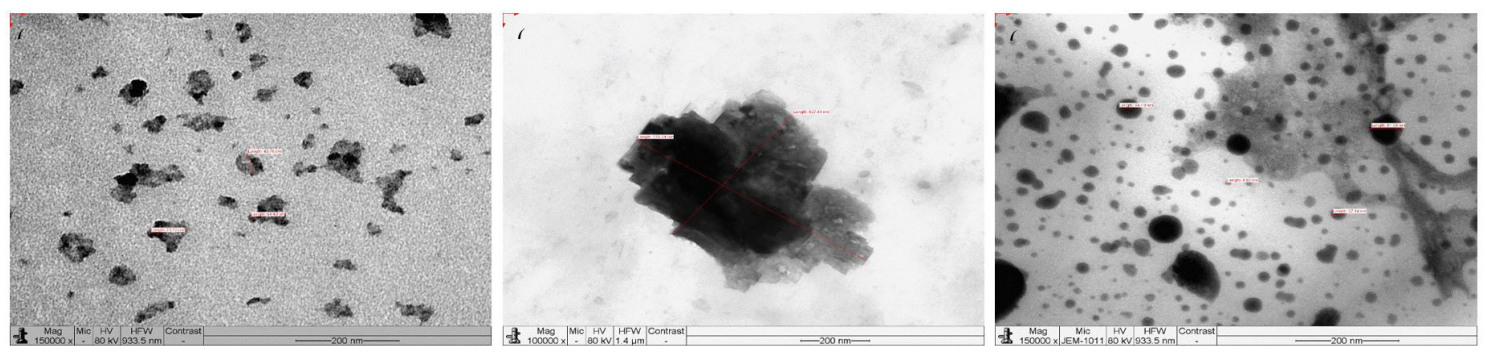

Figure 1. SEM images of the biosynthesized AgNPs. AgNPs were synthesized using seed extract from date palm varieties Iklas, Irziz and Shishi.
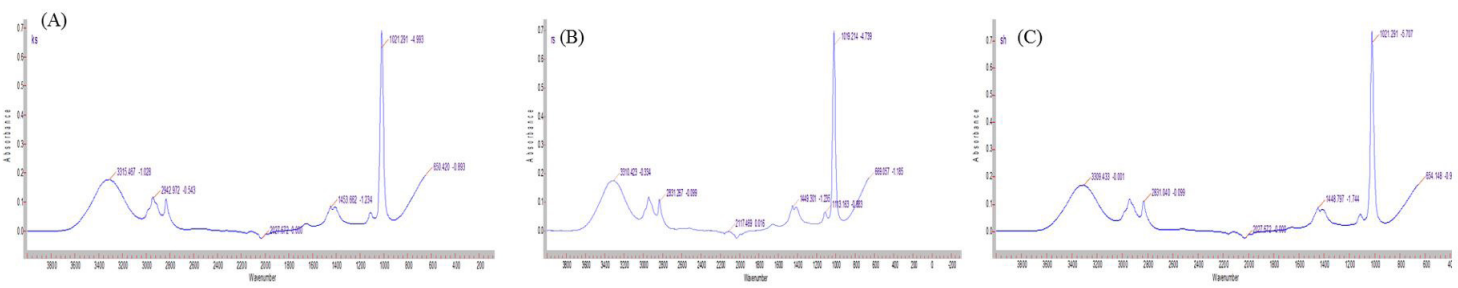

Figure 2. Fourier transform infrared analysis of the biosynthesized AgNPs. AgNPs were synthesized using seed extract from date palm varieties (A) Iklas, (B) Irziz and (C) Shishi.

of $P$. dactylifera, from pale yellow to brown, was visually observed. This indicated the ability of the relevant seed extract to reduce the silver nitrate salt into AgNPs due to existence of chemically-active compounds (e.g., aldehydes, phenols, flavonoids, terpenoids, tannin). Various plant extracts have exhibited potential in reducing metal ions into metal nanoparticles (NPs). Similar findings have been documented in the literature by several authors (Aitenneite et al., 2016; Ansari and Alzohairy 2018; Singh et al., 2018; Zaheer, 2018).

\subsection{Characterization of AgNPs}

SEM images of the AgNPs showed that the NPs were spherical nanospheres and nanoplates in shape, with a size range of $46.79-73.72 \mathrm{~nm}, 8.82-61.06 \mathrm{~nm}$ and $527-776 \mathrm{~nm}$, for NPs formed with seed extracts from Iklas (K-AgNPs), Irziz (R-AgNPs) and Shishi (S-AgNPs) varieties, respectively (Figure 1). These findings correspond to those of Ansari \& Alzohairy, who found similar shapes with smaller size NPs formed by date palm seed extract Ansari and Alzohairy (2018).

For further characterization of the biosynthesised NPs, FTIR was carried out. It is important to investigate the NP surface due to its role in the nanotoxicology by the particles. FTIR is an efficient technique to investigate the synthesis of metal NPs in water solutions. FTIR is a spectroscopy method that can identify variations in the total composition of microorganisms through the determination of changes in functional groups in biomolecules. FTIR measures the vibration and rotation of molecules influenced by infrared radiation at a specific wavelength. This technique allows the identification of structural changes in the molecular binding between microorganisms and metal atoms, which can provide information about the nature of their interactions
We examined the potential interaction between silver ions and the bioactive compounds existing in the date seed extracts. FTIR confirmed their biosynthesis by Phoenix dactylifera (Shishi, Risis and Iklas). The FTIR spectra of the AgNps. (Figure 2) clearly presented that nanosilver particles (Shishi, Iklas and Risis) were shown at 3309.433, 3310.423 and $3315.467 \mathrm{~cm}^{-1}$ overlapping with the $\mathrm{OH}$ signal respectively. At 2027.672, 2027.672 and $2117.469 \mathrm{~cm}^{1}$ there was a $\mathrm{X}=\mathrm{C}=\mathrm{Y}$ allenes, ketenes, isocyanates and isothiocyanates and at 1021.291, 1021.291 and $1019.214 \mathrm{~cm}^{1}$ (Sh, Ik and Rissi, respectively) there was the C-O stretching vibration of alcohols, ether, esters, carboxylic acids and anhydrides. At 664.148, 650,420 and $669.057 \mathrm{~cm} 1$ (Sh, Ik and Rissi, respectively) there was C-X overlapping with chloride, bromide and iodide. The main components of the Phoenix dactylifera is cellulose, which comprises phenolic hydroxyl, benzene ring, double bond, - $\mathrm{O}$-, and other groups. All these functional groups comprise lone electron pairs. When the nano-scale microemulsion was designed in the aqueous phase, these functional groups were dispersed on the surface of the emulsion, display a very strong adsorption capacity. Such findings show the existence of silver AgNPs and indicate the extracts play a key role as stabilizing and reducing agents by which well-dispersed nanoparticles can be synthesised.

\subsection{Antimicrobial activity of the AgNPs}

The results of the antibacterial activities of the green synthesised AgNPs against five virulent bacterial pathogenic strains are presented in Tables 1 and 2. The AgNPs exhibited antibacterial activities against all the pathogenic bacterial strains tested, with a zone of inhibition diameter of $1.0-1.8 \mathrm{~cm}$. The MRSA strain was sensitive to all the AgNPs synthesised from the seed extracts of the three date varieties, as indicated by comparable diameters of the zone 
Table 1. Effects of AgNPs on bacterial viability and inhibition zone size.

\begin{tabular}{cccccc}
\hline Agent & Bacillus subtilis & E.coli & $\begin{array}{c}\text { Methicillin- } \\
\text { resistant }\end{array}$ & $\begin{array}{c}\text { Staphylococcus } \\
\text { aureus }\end{array}$ & $\begin{array}{c}\text { Streptococcus } \\
\text { pneumoniae }\end{array}$ \\
\hline Antibiotic & 3 & 3 & 3 & 3 & 3 \\
K (AgNp) & 1.3 & 1 & 1.1 & 1.2 & 1.4 \\
K (water) & 0.8 & 0 & 0.8 & 0.9 & 0.8 \\
Antibiotic & 3 & 3 & 2.5 & 2.5 & 2.5 \\
R (AgNp) & 1.8 & 1.3 & 1.2 & 1.2 & 1.6 \\
R (water) & 0.9 & 0 & 0.7 & 0.8 & 1 \\
Antibiotic & 2.5 & 3 & 2.5 & 2.5 & 2.5 \\
S (AgNp) & 1.2 & 1.3 & 1.1 & 1.4 & 1.3 \\
S (water) & 1 & 0.7 & 0.9 & 0.8 & 0.8 \\
\hline
\end{tabular}

$\mathrm{K}=$ Iklas extract; $\mathrm{R}=$ Irziz extract; $\mathrm{S}$ = Shishi extract. Extracts added in silver nanoparticles (AgNp); or as aqueous solution (water).

Table 2. Minimum inhibitory concentration of AgNPs on bacterial viability.

\begin{tabular}{|c|c|c|c|c|c|c|c|c|c|}
\hline \multirow{4}{*}{ Bacteria } & \multicolumn{9}{|c|}{ Minimum inhibitory concentration } \\
\hline & \multicolumn{3}{|c|}{ Nanoparticles } & \multicolumn{3}{|c|}{ Aqueous extract } & \multicolumn{3}{|c|}{ Standard } \\
\hline & \multicolumn{3}{|c|}{$\left(\mu \mathrm{g} \mathbf{m L}^{-1}\right)$} & \multicolumn{3}{|c|}{$\left(\mathrm{mg} \mathrm{mL}^{-1}\right)$} & \multicolumn{3}{|c|}{$\left(\mu \mathrm{g} \mathbf{~ m L}^{-1}\right)$} \\
\hline & $\mathbf{K}$ & $\mathbf{R}$ & $\mathbf{S}$ & $\mathbf{K}$ & $\mathbf{R}$ & $\mathbf{S}$ & $\mathbf{K}$ & $\mathbf{R}$ & $\mathbf{S}$ \\
\hline Staphylococcus aureus & 12.5 & 6.25 & 50 & 6.25 & 5 & 6.25 & 25 & 37.5 & 100 \\
\hline Escherichia coli & 32.5 & 12.5 & 25.0 & 0 & 6.25 & 5 & 20 & 25 & 5 \\
\hline Bacillus subtilis & 25.0 & 50 & 12.5 & 5 & 6.25 & 6.25 & 25 & 50 & 25 \\
\hline $\begin{array}{l}\text { methicillin-resistant } \\
\text { Staphylococcus }\end{array}$ & 6.25 & 6.25 & 50 & 5 & 5 & 5 & 25 & 25 & 50 \\
\hline Streptococcus pneumoniae & 50 & 25.0 & 25.0 & 6.25 & 6.25 & 5 & 50 & 25 & 50 \\
\hline
\end{tabular}

$\mathrm{K}=$ Iklas extract; $\mathrm{R}=$ Irziz extract; $\mathrm{S}=$ Shishi extract. Extracts added in silver nanoparticles or as aqueous solution.

of inhibition (1.1, 1.2 and $1.1 \mathrm{~cm}$ for K-AgNPs, R-AgNPs and S-AgNPs, respectively) (Table 1 ). These observations agree with that reported by Ansari \& Alzohairy, who showed that green synthesis of AgNPs using seed extract of P. dactylifera have a potent bactericidal potential against MRSA (Ansari and Alzohairy (2018). Similar antibacterial results have been reported in AgNPs synthesised using various parts of the palm date including fruit extract Zaheer (2018), and leaf extract (Charti et al., 2017).

Unlike the corresponding AgNPs, no obvious zone of inhibition was formed around the aqueous extracts of date seeds against E.coli, indicating that the strain was resistant to both extracts (Table 1). AgNPs have bactericidal activity against E.coli most likely due to the toxicity of silver ions. Interaction of AgNPs with the walls of E. coli have been shown to result in cracking of the cell wall via pit formation, leading to cell death (Sánchez-López et al., 2020). Aqueous extracts of date seeds showed lower antimicrobial activities against the tested strains than their corresponding AgNPs. This finding highlights the potent bactericidal effects of AgNPs via mechanisms need to be deciphered (Sánchez-López et al., 2020).

The mechanisms via which Ag ions exert their inhibitory actions against microbes are not fully understood. It has been argued that $\mathrm{Ag}+$ ions are attracted to the negative charges in the microbial membranes and peptidoglycan in the cell walls via electrostatic attraction (Wu et al., 2020). Consequently, severe disturbance of permeability and the respiratory system takes place, leading to bacterial death. AgNPs have a very tiny size and large surface area that enable them to enter easily the cell and reach the nuclear region of the bacteria (Sánchez-López et al., 2020).. Silver ions could also result in impairment enzymes involved in vital metabolic pathways such as respiratory chains, by interacting with sulfhydryl groups in bacterial proteins. Additionally, the toxicity of silver ions can be mediated via prevention of DNA replication in the bacterial cells (Sánchez-López et al., 2020).

The MIC of the AgNPs ranged 32.5-50 $\mathrm{g} \mathrm{mL}^{-1}$ (Table 2). Against E. coli, K-AgNPs exhibited the lowest level of antibacterial activity with $32.5 \mu \mathrm{g} \mathrm{mL}^{-1}$. However, the lowest level of antibacterial activity observed $\left(50 \mu \mathrm{g} \mathrm{mL}^{-1}\right)$ was reported with K-AgNPs (against Strept. pneumoniae), R-AgNPs (against B. subtilis) and S-AgNPs (against S. aureus and MRSA) (Table 2). The MIC value for R-AgNPs and K-AgNPs against MRSA were similar $\left(62.5 \mu \mathrm{g} \mathrm{mL} \mathrm{m}^{-1}\right)$. These are substantially higher MIC values than those in a study by Ansari, \& Alzohairy who reported that the MIC 
of AgNPs for MRSA was found to be $10.67 \pm 0.94$ (Ansari and Alzohairy (2018). This indicates the variability of the bactericidal capabilities of AgNPs synthesised with different seed extracts of various varieties of date palm.

\subsection{Mechanism of the antimicrobial activity of the AgNPs}

We next investigated the mechanism of the anti-bacterial effects of the seed extract nanoparticles. Exposure of bacterial strains S. aureus and B. cereus to K-AgNPs, R-AgNPs and S-AgNPs resulted in a significant increase in ALP activity (Figure 3). ALP activity was impacted only weakly at low AgNP concentrations. The ALP enzyme is located in association with the plasma membrane in Gram-positive bacteria and within the periplasmic space of Gram-negative bacteria, and elevated levels may indicate disruption of the bacterial cell walls.

Membrane potential (membrane voltage) is defined as the difference in electric potential between the interior and the exterior of a bacterial cell. It plays a pivotal role in transporting ions and metabolites across the membrane and drives ATP production. Addition of K-AgNPs, $\mathrm{R}$-AgNPs and S-AgNPs to $S$. aureus and B. cereus resulted in a significant change of the membrane potential toward a negative value, indicating damage of the membrane integrity (Figure 4). Consequently, leakage of essential ions and metabolites out of the bacterial cells are likely to have taken place. These findings support those of a study by Singh et al. who reported that the plasma membrane was the main target of silver ion toxicity via depolarization of the plasma membrane, which leads to induction of ion leakage, inhibition of bacteria respiration and eventually bacterial cell death (Singh et al., 2018). In the same study, it was reported that silver ions induced rapid cell death, decreasing the possibility of emergence of bacterial resistant strains (Singh et al., 2018).

LDH leakage assays are a common technique used to assess membrane integrity, thereby elucidating the in vitro cytotoxicity of AgNPs (Cho et al., 2008) and other drugs. In addition to glyceraldehyde-3-phosphate dehydrogenase, or adenylate kinase, LDH is localized mainly within the living cells. However, LDH activity is significantly increased extracellularly implying loss of membrane integrity and eventually cell death. Despite limitations, LDH is an efficient tool for assessing membrane integrity and cell death. AgNPs primarily interact with the plasma membrane of bacterial cells and negatively affect the membrane integrity and architecture, leaking cytoplasmic substances such as LDH (Wu et al., 2020). In the present study, there was a substantial increase in the specific activity of LDH of S. aureus and B. cereus exposed to K-AgNPs, R-AgNPs and S-AgNPs (Figure 5). LDH release rose by 32,44 and $65 \%$ when treated with $1 \mathrm{mM}$ of K-AgNPs, R-AgNPs and S-AgNPs, respectively, relative to the control (Figure 5). These results agree with that of Wu et al. who reported that LDH release was substantially increased upon treating Pseudomonas stutzeri with AgNPs (de Lacerda Coriolano et al., 2021).

Proteomic approaches conducted by Yan et al., demonstrated that the cell membrane is the main target of AgNPs (Tian et al., 2018). The potent antibacterial

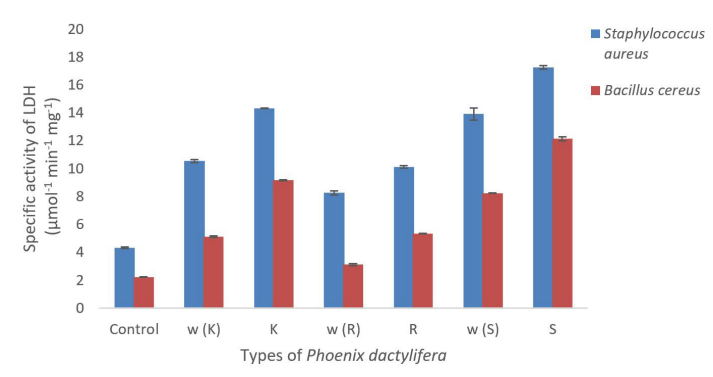

Figure 3. Effect of Phoenix dactylifera seed extracts on bacterial alkaline phosphatase activity. One unit of alkaline phosphatase (ALP) activity was defined as the amount of the enzyme yielding one micromole of $p$-nitrophenol within one minute per milligram protein under the assay conditions. Silver nanoparticles formed from seed extracts from varieties Iklas (K), Irziz (R) and Shishi (S) were compared, with aqueous extracts designated by $w$. Values are mean $(\mathrm{n}=3) \pm S E$.

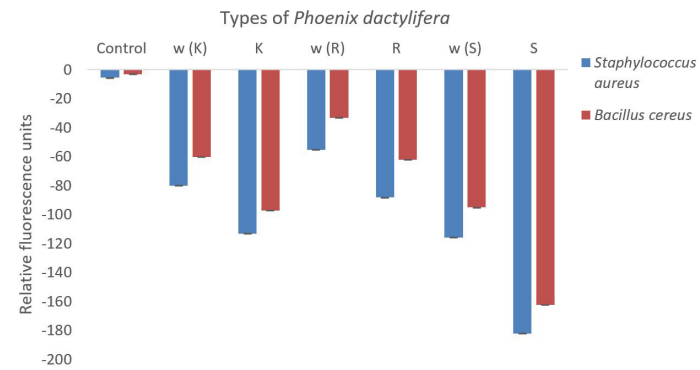

Figure 4. Effect of Phoenix dactylifera seed extracts on bacterial membrane potential. Silver nanoparticles formed from seed extracts from varieties Iklas (K), Irziz (R) and Shishi (S) were compared, with aqueous extracts designated by $w$. Values are mean $(n=3) \pm S E$.

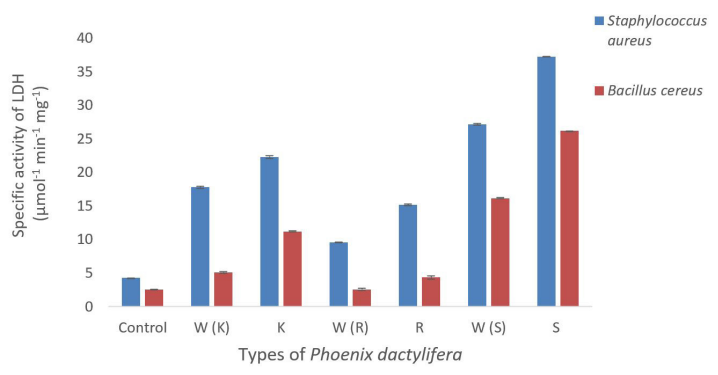

Figure 5. Effect of Phoenix dactylifera seed extracts on the specific activity of lactate dehydrogenase. Silver nanoparticles formed from seed extracts from varieties Iklas (K), Irziz (R) and Shishi (S) were compared, with aqueous extracts designated by w. Values are mean $(n=3) \pm S E$.

capabilities of AgNPs are largely attributed to: (1) oxidative stress resulted from highly reactive oxygen species and (2) loss of membrane integrity resulted from alteration of membrane potential, which causes damage to the cell membrane (Tian et al., 2018). S. aureus and B. cereus, however, are Gram-positive strains that are characterized by the presence of a thick layer of peptidoglycan compared 
to that of Gram-negative strains, which may protect the cells against the deleterious effects of toxic substances. It has been evidenced that AgNPs are active against both Gram-negative and Gram-positive strains, confirming their broad range efficiency against various bacterial species.

\section{Conclusion}

AgNPs were synthesised using seed extracts of three economically important varieties of date palm (Iklas, Irziz and Shishi) then characterised using electron microscopy and Fourier transform infrared analyses. AgNPs exhibited potential bactericidal activities against five different bacterial pathogens, including methicillin-resistant Staphylococcus aureus and Streptococcus pneumoniae. AgNPs exerted their cytotoxic effects via disruption plasma membrane integrity. Green synthesis of AgNPs is an efficient, cost-effective and promising strategy to combat virulent antibiotic-resistant strains.

\section{Acknowledgements}

This work was supported by the Deanship of Scientific Research at King Faisal University (Nasher track Grant No. 18602).

\section{References}

AITENNEITE, H., ABBOUD, Y., TANANE, O., SOLHY, A., SEBTI, S. and EL BOUARI, A., 2016. Rapid and green microwave-assisted synthesis of silver nanoparticles using aqueous Phoenix Dactylifera L. (date palm) leaf extract and their catalytic activity for 4-Nitrophenol reduction. Journal of Materials and Environmental Science, vol. 7, no. 7, pp. 2335-2339.

AL-BRAHIM, J.S. and MOHAMMED, A.E., 2020. Antioxidant, cytotoxic and antibacterial potential of biosynthesized nanoparticles using bee honey from two different floral sources in Saudi Arabia. Saudi Journal of Biological Sciences, vol. 27, no. 1, pp. 363-373. http://dx.doi.org/10.1016/j.sjbs.2019.10.006. PMid:31889859.

ANANDARADJE, A., MEYAPPAN, V., KUMAR, I. and SAKTHIVEL, N., 2020. Microbial synthesis of silver nanoparticles and their biological potential. In: A. SHUKLA, editor. Nanoparticles in medicine (pp. 99-133). Singapore: Springer. http://dx.doi. org/10.1007/978-981-13-8954-2_4.

ANSARI, M.A. and ALZOHAIRY, M.A., 2018. One-pot facile green synthesis of silver nanoparticles using seed extract of Phoenix dactylifera and their bactericidal potential against MRSA. Evidence-Based Complementary and Alternative Medicine: eCAM, 1860280. http://dx.doi.org/10.1155/2018/1860280.

ARASU, M.V., DURAIPANDIYAN, V. and IGNACIMUTHU, S., 2013. Antibacterial and antifungal activities of polyketide metabolite from marine Streptomyces sp. AP-123 and its cytotoxic effect. Chemosphere, vol. 90, no. 2, pp. 479-487. http://dx.doi. org/10.1016/j.chemosphere.2012.08.006. PMid:22963878.

AROKIYARAJ, S., CHOI, S.H., LEE, Y., BHARANIDHARAN, R., HAIRULISLAM, V.I., VIJAYAKUMAR, B., OH, Y.K., DINESH-KUMAR, V., VINCENT, S. and KIM, K.H., 2014. Characterization of ambrette seed oil and its mode of action in bacteria. Molecules (Basel, Switzerland), vol. 20, no. 1, pp. 384-395. http://dx.doi. org/10.3390/molecules20010384. PMid:25551188.
BALU, S., ANDRA, S., KANNAN, S. and MUTHALAGU, M., 2020. Facile synthesis of silver nanoparticles with medicinal grass and its biological assessment. Materials Letters, vol. 259, pp. 126900. http://dx.doi.org/10.1016/j.matlet.2019.126900.

BANU, H., RENUKA, N., FAHEEM, S.M., ISMAIL, R., SINGH, V., SAADATMAND, Z., KHAN, S.S., NARAYANAN, K., RAHEEM, A., PREMKUMAR, K. and VASANTHAKUMAR, G., 2018. Gold and silver nanoparticles biomimetically synthesized using date palm pollen extract-induce apoptosis and regulate p53 and Bcl-2 expression in human breast adenocarcinoma cells. Biological Trace Element Research, vol. 186, no. 1, pp. 122-134. http://dx.doi.org/10.1007/s12011-018-1287-0. PMid:29552710.

CHARTI, I., EDDAHBI, A., ABBOUD, Y. and EL BOUARI, A., 2017. Rapid and green microwave-assisted synthesis of silver nanoparticles using aqueous Phoenix dactylifera L. (Date Palm) wood extract and evaluation of catalytic and antibacterial activities. Micro and Nanosystems, vol. 9, no. 2, pp. 134-139. http://dx.doi.org/ 10.2174/1876402910666180115114616.

CHO, M.H., NILES, A., HUANG, R., INGLESE, J., AUSTIN, C.P., RISS, T. and XIA, M., 2008. A bioluminescent cytotoxicity assay for assessment of membrane integrity using a proteolytic biomarker. Toxicology In Vitro, vol. 22, no. 4, pp. 1099-1106. http://dx.doi. org/10.1016/j.tiv.2008.02.013. PMid:18400464.

DE LACERDA CORIOLANO, D., DE SOUZA, J.B., BUENO, E.V., MEDEIROS, S.M.F.R.D.S., CAVALCANTI, I.D.L. and CAVALCANTI, I.M.F., 2021. Antibacterial and antibiofilm potential of silver nanoparticles against antibiotic-sensitive and multidrugresistant Pseudomonas aeruginosa strains. Brazilian Journal of Microbiology: [publication of the Brazilian Society for Microbiology], vol. 52, no. 1, pp. 267-278. PMid:33231865.

FOOD AND AGRICULTURE ORGANIZATION - FAO [online], 2011 [viewed 15 August 2020]. Available from http://www.fao.org/ faostat/en/\#home

http://www.fao.org/faostat/en/\#home

HAMELIAN, M., ZANGENEH, M.M., SHAHMOHAMMADI, A., VARMIRA, K. and VEISI, H., 2020. Pistacia atlantica leaf extract mediated synthesis of silver nanoparticles and their antioxidant, cytotoxicity, and antibacterial effects under in vitro condition. Applied Organometallic Chemistry, vol. 34, no. 1, pp. e5278. http://dx.doi.org/10.1002/aoc.5278.

HELIANTI, I., OKUBO, T., MORITA, Y. and TAMIYA, E., 2007. Characterization of thermostable native alkaline phosphatase from an aerobic hyperthermophilic archaeon, Aeropyrum pernix K1. Applied Microbiology and Biotechnology, vol. 74, no. 1, pp. 107-112. http://dx.doi.org/10.1007/s00253-006-0640-y. PMid:17256119.

LOWRY, O.H.N.J., ROSEBROUGH, N.J., FARR, A.L. and RANDALL, R.J., 1951. Protein measurement with the Folin phenol reagent. The Journal of Biological Chemistry, vol. 193, no. 1, pp. 265-275. http:// dx.doi.org/10.1016/S0021-9258(19)52451-6. PMid:14907713.

MOHAMMADI, G., ZANGENEH, M.M., ZANGENEH, A. and HAGHIGHI, Z.M.S., 2020. Chemical characterization and anti-breast cancer effects of silver nanoparticles using Phoenix dactylifera seed ethanolic extract on 7, 12-Dimethylbenz [a] anthracene-induced mammary gland carcinogenesis in Sprague Dawley male rats. Applied Organometallic Chemistry, vol. 34, no. 1, pp. e5136. http://dx.doi.org/10.1002/aoc.5136.

MOHAMMED, A.E., AL-QAHTANI, A., AL-MUTAIRI, A., AL-SHAMRI, B. and AABED, K., 2018. Antibacterial and cytotoxic potential of biosynthesized silver nanoparticles by some plant extracts. Nanomaterials (Basel, Switzerland), vol. 8, no. 6, pp. 382. http:// dx.doi.org/10.3390/nano8060382. PMid:29849012. 
NAGAJYOTHI, P.C., LEE, S.-E., AN, M. and LEE, K.-D., 2012. Green synthesis of silver and gold nanoparticles using Lonicera Japonica flower extract. Bulletin of the Korean Chemical Society, vol. 33, no. 8, pp. 2609-2612. http://dx.doi.org/10.5012/bkcs.2012.33.8.2609.

NETHRADEVI, C., SIVAKUMAR, P. and RENGANATHAN, S., 2012. Green synthesis of silver nanoparticles using Datura metal flower extract and evaluation of their antimicrobial activity. Int. J. Nanomater. Biostruct., vol. 2, pp. 16-21.

PILAQUINGA, F., AMAGUAÑA, D., MOREY, J., MONCADA-BASUALTO, M., POZO-MARTÍNEZ, J., OLEA-AZAR, C., FERNÁNDEZ, L., ESPINOZA-MONTERO, P., JARA-NEGRETE, E., MENESES, L., LÓPEZ, F., DEBUT, A. and PIÑA, N.. 2020. Synthesis of Silver nanoparticles using aqueous leaf extract of Mimosa albida (Mimosoideae): characterization and antioxidant activity. Materials(Basel), vol. 13, no. 3, pp. 503. http://dx.doi.org/10.3390/ ma13030503. PMid:31973124.

SÁNCHEZ, E., GARCÍA, S. and HEREDIA, N., 2010. Extracts of edible and medicinal plants damage membranes of Vibrio cholerae. Applied and Environmental Microbiology, vol. 76, no. 20, pp. 68886894. http://dx.doi.org/10.1128/AEM.03052-09. PMid:20802077.

SÁNCHEZ-LÓPEZ, E., GOMES, D., ESTERUELAS, G., BONILLA, L., LOPEZMACHADO, A.L., GALINDO, R., CANO, A., ESPINA, M., ETTCHETO, M., CAMINS, A., SILVA, A.M., DURAZZO, A., SANTINI, A., GARCIA, M.L. and SOUTO, E.B., 2020. Metal-based nanoparticles as antimicrobial agents: an overview. Nanomaterials (Basel, Switzerland), vol. 10, no. 2, pp. 292. http://dx.doi.org/10.3390/ nano10020292. PMid:32050443.

SINGH, H., DU, J., SINGH, P. and YI, T.H., 2018. Extracellular synthesis of silver nanoparticles by Pseudomonas sp. THG-LS1. 4 and their antimicrobial application. Journal of Pharmaceutical
Analysis, vol. 8, no. 4, pp. 258-264. http://dx.doi.org/10.1016/j. jpha.2018.04.004. PMid:30140490.

TANASE, C., BERTA, L., MARE, A., MAN, A., TALMACIU, A.I., ROȘCA, I., MIRCIA, E., VOLF, I. and POPA, V.I., 2020. Biosynthesis of silver nanoparticles using aqueous bark extract of Picea abies L. and their antibacterial activity. European Journal of Wood and Wood Products, vol. 78, no. 2, pp. 281-291. http://dx.doi.org/10.1007/ s00107-020-01502-3.

TIAN, X., JIANG, X., WELCH, C., CROLEY, T.R., WONG, T.Y., CHEN, C., FAN, S., CHONG, Y., LI, R., GE, C., CHEN, C. and YIN, J.J., 2018. Bactericidal effects of silver nanoparticles on lactobacilli and the underlying mechanism. ACS Applied Materials E Interfaces, vol. 10 , no. 10 , pp. $8443-8450$. http://dx.doi.org/10.1021/ acsami.7b17274. PMid:29481051.

WU, L., ZHU, G., ZHANG, X. and SI, Y., 2020. Silver nanoparticles inhibit denitrification by altering the viability and metabolic activity of Pseudomonas stutzeri. The Science of the Total Environment, vol. 706, pp. 135711. http://dx.doi.org/10.1016/j. scitotenv.2019.135711. PMid:31791784.

ZAFAR, S. and ZAFAR, A., 2019. Biosynthesis and characterization of silver nanoparticles using Phoenix dactylifera fruits extract and their in vitro antimicrobial and cytotoxic effects. The Open Biotechnology Journal, vol. 13, no. 1, pp. 37-46. http://dx.doi.or g/10.2174/1874070701913010037.

ZAHEER, Z., 2018. Biogenic synthesis, optical, catalytic, and in vitro antimicrobial potential of Ag-nanoparticles prepared using Palm date fruit extract. Journal of Photochemistry and Photobiology. B, Biology, vol. 178, pp. 584-592. http://dx.doi.org/10.1016/j. jphotobiol.2017.12.002. PMid:29272851. 